\title{
Market Participation of Smallholder Pigeon Pea Farmers in Makueni County, Kenya
}

\author{
Karanja, J.W.* Lagat J.K. Mutai B.K. \\ Department of Agricultural Economics and Agribusiness Management, Faculty of Agriculture, Egerton \\ University, Njoro, Kenya
}

\begin{abstract}
This study sought to assess the factors that influence market participation of the smallholder pigeon pea farmers in Makueni County, Kenya. A stratified sampling procedure was used to obtain information from 198 respondents and the information was captured through the use of a structured questionnaire. Results show that $70 \%$ of the farmers in the study participated in the market as sellers. A Tobit Model was used to analyse the socio economic and institutional factors affecting participation. The results revealed that gender of household head, household size, off-farm income, price, membership to a farmer's organization and access to market information influenced market participation. This study recommends first, the intensified use of improved pigeon pea cultivar to increase the marketable surplus. Secondly, strengthening and transformation of the existing farmer organisations into marketing groups so as to enhance market linkages to more lucrative markets and reduce transaction costs. Thirdly, investment in telecommunication platforms so as to ensure timely market information such as price, quantities and varieties required are disseminated to the farmers e.g. through mobile phones.
\end{abstract}

Keywords: market participation, smallholder farmers, pigeon pea

DOI: $10.7176 / \mathrm{JESD} / 10-16-12$

Publication date: August $31^{\text {st }} 2019$

\section{Introduction}

Agriculture plays a major role in most developing and transition economies. In Kenya, the agricultural sector is the second largest contributor to the country's GDP at 24\% (KNBS, 2012) and with a multiplier effect of 1.64 to the non-agricultural sector. Agriculture supports the livelihoods of more than $60 \%$ of the rural population (Omiti et al, 2009). This sector has also been envisaged as one of the six key sectors expected to spur and maintain an economic growth of $10 \%$ under Vision 2030 (GoK, 2007). It also plays a vital role in the achievement of the first Millennium Development Goal (MDG 1) that strives to eradicate poverty and hunger.

Smallholder farmers in Kenya account for over $75 \%$ of the total agricultural output and about $50 \%$ of the marketable produce (GoK, 2007). However, these farmers are typified by low equilibrium poverty trap (Barret, 2009). This is a situation of low investments that leads to low productivity and consequently low marketable surplus (low returns). For the agricultural sector to make a significant contribution to economic growth and improve rural livelihoods, the sector needs to be commercialized to enable smallholder farmers to participate in markets (Jagwe et al., 2010). Agricultural transformation is therefore a necessary condition in their transition out of poverty.

Agricultural production in most countries in sub Saharan Africa has mainly been characterized by growing of food crops primarily targeted for own consumption with very little marketable surplus. The leap required in African agriculture to reduce poverty and hunger is a transformation from the low productivity semi-subsistence farming to high level commercial farming (Siziba et al., 2011). Agricultural commercialization involves the transition from subsistence to increasingly market-oriented production and the use of high quality input; a process is mainly driven by globalization, urbanization, migration and rising per capita income (Omiti et al., 2007). Most development strategies in Kenya such as Strategy for Revitalising Agriculture (SRA) and the Agricultural Sector Development Strategy (ASDS) recognize the contribution of smallholder agriculture to the national income, employment, food and nutrition security. A major concern in these strategies has been how to improve rural livelihoods in the Arid and Semi-Arid Lands (ASALs) through enhancing the potential of crops, pulses being amongst these crops. Pulses are an important dietary protein source in Kenya and especially in ASALs (FAO, 2008). The most common type of legumes cultivated in the semi-arid eastern Kenya include beans (Phaseolus vulgaris L.), pigeon peas (Cajanus cajan (L.)Millsp), cowpeas (Vigna unguiculata L.) and green grams (Vigna radiate Wilczek). Pigeon pea (Cajanus cajan) accounts for about 5 percent of the world's pulse production and is mainly grown in Asia, Latin America and Caribbean countries and Sub Saharan Africa (FAO, 2007). According to FAOSTAT (2012), Kenya ranks fifth in global pigeon pea production after India, Myanmar, Malawi and Tanzania with a production of 89,390 Metric Tons in 2012. Pigeon pea accounts for 14 percent of the total land area under pulses and 16 percent of the total output of pulses in Kenya, making it the second important pulse after beans, in both area and production (Simtowe et al., 2012).This leguminous crop is mainly cultivated by smallholder farmers in Arid and Semi-Arid Lands (ASALs) as a source of food and cash (Shiferaw et al., 2007).

According to Kimiti et al. (2009), about 90 percent of the total land area under pigeon pea is in the eastern 
part of the country. The introduction of new cultivars has led to the increase in productivity of this dry land crop (Gathetcha et al., 2012). Despite the smallholder farmers in this region having a comparative advantage in the production of this food crop to their counterparts, they have not optimally exploited this to improve their livelihoods. Shiferaw et al. (2007) observes that though there is a large market both domestically and internationally, a significant part of the market still remains unexplored. In the local context, the high value markets such as supermarkets, urban retailers and wholesalers and the exporters largely remain untapped (USAID, 2010).

\subsection{Statement of the problem}

The productivity of smallholder pigeon pea farmers in Arid and Semi-Arid regions has improved due to the adoption of high yielding and early maturing pigeon pea cultivars in the eastern part of Kenya. Despite the existence of market for pigeon peas, market participation of the smallholder farmers is low. The main drivers impeding market participation still remain unclear. This study therefore aimed at examining the socio-economic factors as well as the institutional factors influencing market participation for these smallholder farmers.

\subsection{Objectives of the study}

The general objective of the study was to contribute to the increase in income levels of smallholder pigeon pea farmers in Makueni County through market participation. The specific objectives were;

i) To characterize the smallholder pigeon pea farmers in Makueni County.

ii) To determine the socio-economic and institutional factors influencing market participation of smallholder pigeon pea farmers.

\subsection{Research questions}

i. What are the characteristics of smallholder pigeon pea farmers in Makueni County?

ii. What are the socio-economic and institutional factors that influence market participation of smallholder pigeon pea farmers.

\subsection{Methodology \\ 2.1 Study Area}

This study was conducted in Makueni County which is located in the south-eastern part of the country and borders four counties; Kitui to the east, Taita Taveta to the south, Kajiado to the west and Machakos to the north. It covers a total area of $8,034.7 \mathrm{Km} 2$ and lies between latitude $1^{\circ} 35^{\prime}$ and $3^{\circ} 00$ South and longitude $37^{\circ} 10^{\prime}$ and $38^{\circ} 30^{\prime}$ East .The population is approximately 884,527 people with a population density of 110 people per $\mathrm{km} 2$. Administratively, the county is divided into six constituencies, nine sub-counties and twenty five divisions. The gender of the population is almost equally distributed with 49 percent of the population being male and 51 percent being female. The population growth rate is 1.4 percent. Approximately, 34 percent of the population living in the urban areas and 66 percent in the rural areas live under the poverty line (GoK, 2009).

The county has a varied agro-ecological zone ranging from high, medium and low potentials. Temperature ranges from $12^{\circ} \mathrm{C}$ to $28^{\circ} \mathrm{C}$ with the highlands receiving rainfall of between 800 to $1200 \mathrm{~mm}$ per year while the lowlands receive 200-900 mm of rainfall per year. Long rains are from March to April while short rains are from November to December. The three main soil types in this area are red clay soils, sandy soils and black cotton soils. The main economic activity is agriculture albeit having several tourist attraction sites such as Tsavo National Park. The major cash crops are coffee in the Highland zones while fruits (mangoes, paw paws and watermelons) and horticultural crops (onions, vegetables, potatoes, lentils and chilies) are grown in the lowland zones. The lowland region has insufficient rain and experiences frequent and prolonged periods of drought due to arid and semi-arid climatic conditions. Farming is mainly subsistence and the major cereals are maize, finger millet and sorghum. Legumes grown include beans, cow peas, pigeon peas, green grams, groundnuts and chick pea whereas the main root tubers are sweet potatoes and cassava. Dairy farming and bee keeping is also common in this area.

\subsection{Sampling Design}

The sample unit for this study was the head of household among smallholder pigeon pea farmers in Makueni County. A multistage sampling technique was used to select the respondent farmers. In the first stage, one (Makueni Constituency) out of six constituencies was purposively selected since it is the main pigeon pea producing area in the county. In the second stage, Kathonzweni Sub-county was purposively selected. Three wards (Kathonzweni, Kitise and Mavindi) were purposively selected due to the large number of smallholder farmers in these areas. The sample size consisted of 198 respondents as determined by equation (4) below. A sample size that was proportionate to the population in each location was picked using Simple random sampling technique.

\subsection{Sample size determination}

The required sample size was determined by proportionate to size sampling methodology (Anderson et al., 2007). 


$$
\mathrm{n}=\frac{\mathrm{pqZ}^{2}}{\mathrm{E}^{2}}
$$

Where $n=$ sample size, $p=$ proportion of the population containing the major interest, $q=1-p, z=$ confidence level $(\alpha=0.05), E=$ acceptable/allowable error. Hence, $\mathrm{Z}=1.96, p=0.13\left(\frac{7485}{56932}\right), \mathrm{q}=0.87$ and $\mathrm{e}=0.05 .198$ respondents were therefore be used as the sample size.

\subsection{Analytical framework}

The data collected with regard to the objectives were analyzed as follows:

\subsubsection{Objective 1: Characterization of smallholder pigeon pea farmers}

Descriptive statistics was used to analyse the household characteristics and other socio economic factors of the smallholder farmers.

\subsubsection{Objective 2: Effect of socio-economic and institutional factors on market participation}

The Tobit model was used to determine factors affecting market participation and the extent of engagement in trade. The censored regression model is viewed effectively as a hybrid between a standard regression model and a binary model (Dougherty, 2003). It assumes that factors influencing a household's decision to engage in trade simultaneously affect the intensity of market participation.

The hypothesized relationship was;

$$
\text { Where } Y_{\mathrm{i}}=\left\{\begin{array}{l}
y_{i}^{*} \text { if } y_{i}^{*}>T \\
T y \text { if } y * \leq T
\end{array} \quad\right. \text { (left censoring) }
$$

$$
Y_{i}^{*}=\beta_{i}+\beta_{i} X_{i}+\mu_{i}
$$

$\mathrm{T}$ is the lower boundary and assumes a value of zero where the household did not participate in the sale of pigeon pea. $\mathrm{Y}_{\mathrm{i}}$ is the observed dependent variable (proportion of output sold) while $Y_{i}^{*}$ is the latent variable. $X_{i}$ represents the set of covariates that influence the dependent variable. $\beta$ is the parameter to be estimated and $\mu_{i}$ is the disturbance term. The empirical model used to estimate the decision to participateand the extent of market participation among the smallholder pigeon pea farmers is as given below;

$$
\mathrm{Y}_{\mathrm{i}}=\beta_{0}+\beta_{1} \text { Gender }+\beta_{2} \text { Age }+\beta_{3} \text { HHsize }+\beta_{4} \text { Educ }+\beta_{5} \text { Landsize }+\beta_{6} \text { Off-FmInc }+\beta 7 \text { QtyProd }+\beta_{8}
$$

Price $+\beta_{9}$ MktDist $+\beta_{10}$ RoadCon $+\beta_{11}$ Memb $+\beta_{12}$ ContExt $+\beta_{13}$ MktInfor $+\beta_{14}$ Creditaccs $+\mu_{i}$

\section{Results and Discussion}

Out of the 198 respondents interviewed, $136(69 \%)$ sold their produce to the market while $62(31 \%)$ did not. The socio-economic characteristics of the households were divided into two categories: first, household characteristics that included the gender of the household head, age, household size, land size, family members, off- farm income, total income from farming, quantity of pigeon pea produced during the previous season and the amount of pigeon pea consumed from the harvest. The second category was the market and institutional factors which comprised of the distance to the market, price at which the farmer sold his or her output, road condition, membership to any

\begin{tabular}{|c|c|c|c|c|c|c|}
\hline \multirow[b]{2}{*}{ Variable } & \multicolumn{2}{|c|}{$\begin{array}{c}\text { Participants } \\
n=136\end{array}$} & \multicolumn{2}{|c|}{$\begin{array}{c}\text { Non-Participants } \\
n=62\end{array}$} & \multicolumn{2}{|c|}{$\begin{array}{c}\text { Whole sample } \\
n=198\end{array}$} \\
\hline & Mean & $\begin{array}{l}\text { Standard } \\
\text { deviation }\end{array}$ & Mean & $\begin{array}{l}\text { Standard } \\
\text { deviation }\end{array}$ & Mean & $\begin{array}{l}\text { Standard } \\
\text { deviation }\end{array}$ \\
\hline Age & 48.23 & 14.06 & 45.50 & 11.77 & 47.37 & 13.415 \\
\hline Education (Years of Schooling) & 8.51 & 4.01 & 9.60 & 9.67 & 8.85 & 3.83 \\
\hline Household size & 5.44 & 2.04 & 5.89 & 27.42 & 5.58 & 2.08 \\
\hline Land size & 3.32 & 1.23 & 2.71 & 37.10 & 3.13 & 1.28 \\
\hline Off-farm Income & $49,915.15$ & $42,2017.07$ & $55,818.97$ & $63,314.77$ & $46,159.47$ & $49,849.36$ \\
\hline Farming Income & $19,048.53$ & $20,321.68$ & $13,358.06$ & $24,779.62$ & $17,226.67$ & $21,911.90$ \\
\hline Quantity Produced & 294.09 & 443.85 & 76.81 & 82.25 & 226.05 & 383.80 \\
\hline Quantity Consumed & 72.77 & 41.29 & 64.47 & 52.83 & 70.17 & 45.25 \\
\hline
\end{tabular}
farmer Organization, contact with extension functionaries, access to information and access to credit. Results for the first category are as shown below in Table 3.

Table 3: Household characteristics

Results in Table 3 above show that the respondents had acquired formal education that was equivalent to form one education (nine years).Education was expected to have a positive influence on the market participation decision. According to Nuri (2018), the education background determines the readiness of the household head to accept new ideas and innovations, and easy to get supply, demand, and price information. The average years of schooling for participants was 8.5 years while that of non-participants was 9.5 years. The independent sample ttest revealed that there was a difference at $10 \%$ level of significance on the average years of schooling between the participants and non-participants. The results above are consistent with the ones obtained by Mango et al., 
(2018), where the odds of participation in the groundnut market for farmers who had attained either primary or secondary school level were approximately three times as high as the odds of farmers who had not attained either of the two educational levels.

Land is viewed as a critical factor in agricultural production hence the larger the parcel, the higher the output and the probability of market participation. The mean land size owned was 3.13 hectares. Participants had slightly larger parcels of land $(3.32 \mathrm{Ha})$ than the non-participants who owned $2.71 \mathrm{Ha}$. The independent sample t-test indicated that there was a difference at $1 \%$ level of significance in the mean of the land holding size of the two groups. These results are in agreement with the one observed in the study by Mango et al., (2018).

It was also observed that farmers who engaged in trade of pigeon pea had a higher farming income (KES. 19,048) compared to those who did not participate in the trade (KES. 13,358). This is because the proceeds from the sale of pigeon pea contributed to up to $30 \%$ of the total farming income. The independent sample t-test revealed that there was a difference at $10 \%$ level of significance on the mean value of household farming income from the two categories. However, households which did not participate in the sale of pigeon pea had a higher off-farm income (KES. 55,818) as compared to those who sold part of their pigeon pea output (KES. 41,915). This difference was significant at 10\% significance level as indicated by the independent sample t-test.

The average quantity of pigeon pea produced by the households was $226.05 \mathrm{kgs}$. Households who sold their produce to the market produced $294.09 \mathrm{kgs}$ while their counterparts produced $76.81 \mathrm{kgs}$. There was a statistically significant difference in the output of the two groups at $1 \%$ level of significance. As it had been assumed, a large quantity produced translated into a higher marketable surplus, ceteris paribus.

Table 5: Access to extension services, market information, credit and membership to farmer organizations

\begin{tabular}{lllccccccc}
\hline & & \multicolumn{2}{c}{ Participants } & \multicolumn{2}{c}{ Non-Participants } & \multicolumn{2}{c}{ Overall } & \\
& & & Frequency & \% & Frequency & \% & Frequency & \% & $\boldsymbol{\chi}^{\mathbf{2}}$ \\
\hline Access to & Extension & Yes & 82 & 41.41 & 41 & 20.71 & 123 & 62.12 & 0.616 \\
Services & & No & 54 & 27.27 & 21 & 10.61 & 75 & 37.88 & \\
Membership in Farmer & Yes & 94 & 47.47 & 40 & 20.20 & 134 & 67.68 & 0.412 \\
Organisation & & No & 42 & 21.21 & 22 & 11.11 & 64 & 32.32 & \\
Access to & \multirow{2}{*}{ Market } & Yes & 131 & 66.16 & 44 & 22.22 & 175 & 88.38 & $26.67^{* * *}$ \\
Information & & No & 5 & 2.53 & 18 & 9.09 & 23 & 11.62 & \\
Access to Credit & Yes & 50 & 25.25 & 62 & 31.31 & 60 & 30.30 & $8.59^{* *}$ \\
& & No & 86 & 43.43 & 52 & 26.26 & 138 & 69.70 & \\
\hline
\end{tabular}

Membership in a farmer organization is an indicator of collective action amongst farmers. Collective action helps the smallholder farmers to bulk their produce thus enjoy economies of scale especially in transportation costs. Farmers, through their groups, can also have a better bargaining power. To the buyer, bulking saves time that would have been spent on collecting the harvest from dispersed farmers with often little marketable quantities. About 47 percent of the participants were members of a farmer group and 21 percent were not enrolled in any farmer group. For the non-participants, 20 percent were members of a farmer group while 11 percent did not belong to any farmer organization. The chi-square test indicated that market participation and membership to a farmer group are independent of each other at $10 \%$ significance level.

Market information was accessible to most of the smallholder farmers. About 66 percent of the participants obtained information pertaining to price and potential buyers before selling while 22.2 percent did not. The chisquare test indicated that there was a significant relationship between participation and access to market information at $1 \%$ significance level.

Access to credit enhances the farmer's productivity by enabling them to acquire inputs such as fertilizer and hybrid seeds hence overcoming working capital constraints. Only 25 percent of the participants obtained a credit facility for agricultural use. The major sources of credit were microfinance institutions, self-help groups and banks at 50 percent, 37 percent and 13 percent respectively as illustrated in figure 7 . The chi-square test indicated that there was a statistically significant relationship between acquisition of a credit facility for agricultural use and market participation as a seller at 5\% significance level.

The transportation mode has an influnce on the choice of marketing channel for the farmer and the time taken for the produce to reach the customer. Ownership of a transport means helps reduce the transportation cost and hence the transaction costs. Only 32 percent of the participants owned the means transportation. The most popular modes of transport were as follows: motorcycle (53.94\%), bicycle $(38.18 \%)$, cart $(7.27 \%)$ and pickup $(0.61 \%)$. The chi-square test showed that there was a statistically significant association between the mode of transport and market participation as a seller at 1\% significance level In the study by Mango et al., (2018), farmers who did not have transport information faced challenges in finding ways of delivering their produce to distant markets. It was therefore convinient for them to sell their produce at the farmgate thus reducing their transaction costs.

Econometric analysis results of the Tobit model estimating the factors affecting pigeon pea sales among the smallholder farmers are presented in Table 2. 


\begin{tabular}{|c|c|c|c|}
\hline Variable Name & Marginal Effects & Std. Err. & p-value \\
\hline Gender & 0.072 & 0.041 & $0.082 *$ \\
\hline Age & 0.002 & 0.002 & 0.286 \\
\hline Education & -0.002 & 0.005 & 0.727 \\
\hline Household Size & -0.029 & 0.010 & $0.005 * * *$ \\
\hline Land Size & 0.020 & 0.015 & 0.192 \\
\hline Logarithm of Off-Farm Income & 0.013 & 0.005 & $0.016^{* *}$ \\
\hline Price & 0.015 & 0.001 & $0.000 * * *$ \\
\hline Distance to nearest Market & 0.013 & 0.008 & 0.117 \\
\hline Contact with Extension Officers & -0.001 & 0.038 & 0.986 \\
\hline Membership to a Farmer Group/Organisation & -0.085 & 0.043 & $0.047 * *$ \\
\hline Credit Access & 0.031 & 0.043 & 0.475 \\
\hline Access to Market information & 0.232 & 0.077 & $0.003 * * *$ \\
\hline Constant & -0.411 & 0.139 & $0.003 * * *$ \\
\hline
\end{tabular}

58 left censored observations at SALES $<=0,140$ uncensored observations. ${ }^{*}, * *, * * *$ represents significance of coefficients at $10 \%, 5 \%$ and $1 \%$ respectively.

Gender of the household head had a positive significant effect on market participation at $10 \%$ level. This implies that the probability of a male headed household participating in the pigeon pea market is $7.2 \%$ higher than that of a female headed household. This finding is in tandem with that of Awotide et al., (2013) which found that the probability of participating in the market is higher among the male headed household than the female counterparts.

Household size had a negative significant effect on participation at $1 \%$ level of significance. An increase in the household members by one person caused the probability of participating in the market to decline by $2.87 \%$. A large household size indicates higher consumption of the harvested produce hence little is left for trade. Approximately, $32 \%$ of the produce was utilized by the household. These findings are in agreement with that of a study by Pambo, (2014) which indicated that about 38 percent of the total pigeon pea produced is retained by the farmer for household consumption. The study by Omiti et al., (2009) also established that a large household size significantly reduced the amount of milk sold by peri-urban areas. This was because children did not contribute to farm labour but significantly increased household consumption.

Off-farm income had a positive significant effect on Smallholders' pigeon pea market participation at 1\% level. The positive sign indicates that a unit increase in off farm income increases the chance of market participation by $1.3 \%$. The possible explanation to this is that the households with an off-farm income invest part of this income in agricultural activities. Kuwornu and Owusu, (2012) indicated that participation in off farm income generating activities helps to ease the household financial needs. It also provides additional funds for adequate investment in production technologies and hence a higher marketable output. The output price of pigeon pea had a positive significant effect on market participation at $1 \%$ level of significance. A rise in the price of pigeon pea by one shilling would trigger an increase in the proportion of pigeon pea sold by $1.5 \%$. The average price for the local market channel was KES. 40 per kilogram while that offered by the intermediaries (especially brokers) was KES. 35 per kg. Urban markets offered a slightly higher price of KES. 50 per $\mathrm{kg}$ as compared to the local markets and the brokers. Notably, the farmers who sold their produce to the urban market traded in larger volumes as compared to their counterparts who sold to the local and intermediate markets. Price could therefore be used as an incentive to increase their farming income. These results concur with the findings of Simtowe et al., (2009) where they observed that the rise in pigeon pea export prices was likely to induce exports as it offered a good opportunity for farmers in Malawi to increase their revenue through exports. A similar observation was made in the study by Omiti et al., (2009) where price acted as an incentive that significantly increased the percentage of vegetables sold in both rural and peri-urban areas.

Access to market information had a positive significant influence on market participation of the smallholder pigeon pea farmers at $1 \%$ level. This indicates that accessibility to market information such as price and potential buyers increases the probability of participation by $23.2 \%$. Makoka (2009) pointed out that lack of market information hampered pigeon pea production and was a major barrier to competitiveness in Malawi. These results are also consistent with the one obtained by Ranjeev and Sreekumar (2012), which indicated that an increase in availability of information would result in an increase in both formal and informal market participation. In Omiti et al., (2009), the use of informal market information channels contributed to the increased output sales of milk in both peri-urban and rural areas.

\section{SUMMARY, CONCLUSION AND RECOMMENDATIONS}

This study was carried out in Makueni County to characterize existing pigeon pea farmers. It also identified the factors that influence pigeon pea market participation using the Tobit Model. Only 69\% of the respondents 
participated as sellers in the pigeon pea market. Furthermore, it assessed factors that determined the marketing channel choice using the multinomial logit model. The three major marketing channels used by these sellers were: rural markets $(9.3 \%)$, local market $(79.1 \%)$ and urban markets $(11.6 \%)$. The findings of the study showed that the market participants had significantly larger farming income, land size and quantity of pigeon pea produced than their counterparts. They also had significantly more access to credit and market information. Participation was also significantly affected by ownership of a transport mode, education and off farm income.

Results from the Tobit model showed that the main determinants for market participation were gender, household size, off farm income, price, membership to farmer organization and access to market information. Off farm income, price, and marketing information had a positive and statistically significant effect on the probability of a household participating in the market while gender, household size and membership to farmer organization had a negative and statistically significant influence on the likelihood of participating in the market.

Based on the results of this study, the following recommendations are necessary for increasing the income levels and improve the livelihood of smallholder pigeon pea farmers in Makueni County through market participation: First, intensify the use of improved pigeon pea cultivars in the production systems. This will ensure that the household consumption needs have been met thus contributing to the achievement of food nutrition and security. It will also lead to increased marketable surplus available for trade. Secondly, there is need to strengthen and/or transform the existing farmer organisations into marketing groups so as to enhance the benefits derived from collective action. Investments in social capital links farmers to more lucrative markets such as urban and export markets that have better output prices and higher margins for their produce. Thirdly, Investment in telecommunication platforms so as to ensure information such as price, quantities and varieties required are disseminated to the farmers efficiently and effectively e.g. through mobile phones.

\section{References}

Abdulai, A. (2006). Spatial integration and price transmission in agriculture commodity markets in Sub-Saharan Africa. In Sarris, A. \& Hallman, D., Agriculture Commodity Markets and Trade: New approaches to analyzing market structure and instability. FAO: Fiat Printing.

Agona, A., Muyinza, H. (2005). Promotion of improved handling, processing, utilization and marketing of pigeonpea in Apac District.DFID-NARO 3006. Final Project report.

Alene, A. D., Manyong, V., Omanya, G., Mignouna, H., Bokanga, M., and Odhiambo, G. (2008). Smallholder market participation under transaction costs: Maize supply and fertilizer demand in Kenya. Food Policy, 33(4), 318-328

Barrett, C.B., (2008). Smallholder market participation: Concepts and evidence from Eastern and Southern Africa. Journal of Food Policy, Vol.33 (4):299-317.

Bellamare, M.F. and Barrett C. (2006). An Ordered Probit Model of Market Participation: Evidence from Kenya and Ethiopia. American Journal of Agricultural Economics, Vol 88(2):324-327.

Berhanu, G. and Moti, J. (2012). Market Participation and Market Orientation of smallholders in Ethiopia: Implications for Commercial Transformation. Paper prepared for presentation at the International Association of Agricultural Economists Conference (IAAE), August 18-24 2012,Foz do Iguacu, Brazil.

Boughton, D., Mather, D., Barret, C.B., Benfica, R., Abdula, D., Tschirley, D., and Cunguara, B., (2007). Market Participation by Rural Households in a Low-Income Country: An Asset-Based Approach Applied to Mozambique. Faith and Economics, Vol. 50: 64-101.

Burke, J.W. (2009). Triple hurdle model of Smallholder Production and Market Participation in Kenya's Dairy Sector. Msc Thesis, Department of Agriculture, Food and Resource Economics, Michigan State University, USA.

Calzadilla, A., Zhu,T., Redhanz,R.S.J.Tol., and Ringler, C.(2009). Economicwide Impacts of Climate Change in Sub-Saharan Africa, IFPRI Discussion Paper No.873. International Food Policy Research Institute. Washington D.C.

Cazzuffi, C. and McKay, A. (2012). Rice Market Participation and channels of sale in rural Vietnam. A Paper prepared for presentation at the International Association of Agricultural Economists Conference (IAAE), August 18-24, 2012, Foz do Iguacu, Brazil.

Cragg, J. (1971). "Some Statistical Models for Limited Dependent Variables with Application to the Demand for Durable Goods". Econometrica, vol.39 (5): 829-844.

Fafchamps, M. and Hill, R.V. 2005. Selling at farm gate or travelling to market. American Journal of Agricultural Economics, Vol.87: 717- 734.

Gathetcha, W.C., Bowen, M., Silim, S., and Kochomay, S. (2012). The diffusion of agricultural innovations: The effectiveness of communication channels used in the improved pigeonpea varieties in Makueni County, Kenya. A conference paper presented in the International Conference on Agriculture, Chemical and Environmental Sciences in October 6-7 ,2012, Dubai (UAE).

Government of Kenya (2009). Kenya Census Report, Nairobi. 
Government of Kenya (2010). Kenya vision 2030. Government Printers, Nairobi, Kenya.

Green, W. H. (2003). Econometrics Analysis. $5^{\text {th }}$ Edition. Pearson Education Inc., New Jersey.

Heckman, J. (1979). Sample Selection bias as a specification error. Econometrica, 47:153-161.

Høgh-Jensen H,Myaka FA, Sakala WD, Kamalongo D,Ngwira A, Vesterager JM, Odgaard R, Adu-Gyamfi JJ(2007). Yields and qualities of pigeonpea varieties grown under smallholder farmers' conditions in Eastern and Southern Africa. Afr. J. Agric. Res.,2:269-278.

Jagwe, J., Ouma, E. and Machethe, C. (2010). Transaction costs and smallholder farmer's participation in Banana Markets in the Great Lakes Region

Joshi, P.K. and Rao, P.P. (2017) Global pulses scenario: status and outlook. Annals of the New York Academy of Sciences 1392, 6-17.

Karanja, F.K. Cropwat model analysis of crop water use in six districts in Kenya (2007). Department of Meteorology, University of Nairobi, Kenya.

Key, N., Sadoulet, E. and de Janvry, A. (2000). Transaction Costs and Agricultural Household Supply Response. American Journal of Agricultural Economics, Vol 82(2):245-259.

Kirimi, L., Sitko, N., Jayne, S., Karin, F., Muyanga, M., Sheahan, M., Flock, J. and Bor, G. (2010). Farm gate to consumer value chain analysis of Kenya maize marketing system. Tegemeo Institute of Agricultural Policy and Development. October 2010.

Kohli, A.K., Jaworski, B.J., Kumar, A. (1993). Markor: A Measure of Market Orientation. Journal of Marketing Research, Vol 30(4);pp. 467-477

Ministry of Agriculture (2008). Agricultural Sector Development Strategy. Nairobi.

Morris, M., Kelly, V., Kopicki, R.J., and Byerlee, D (2007). Fertilizer use in African Agriculture: Lessons Learned and Good Practice Guidelines. Washington DC: World Bank.

Mussa, E.S., Simtowe, F., and Obare, G. (2006). Factor productivity in smallholder pigeon pea production systems: Empirical evidence from Northern Tanzania. Journal of Agricultural Economics and Development Vol. 1(6), pp.138-144.

Mwakubo, Samuel \& Obare, Gideon \& Omiti, John \& Mohammed, Lutta. (2006). The Influence of Social Capital on Natural Resource Management in Marginal Areas of Kenya. International Association of Agricultural Economists, 2006 Annual Meeting, August 12-18, 2006, Queensland, Australia. 10.13140/2.1.3802.6242.

Myaka, F.M., Sakala, W.D., Adu-Gyamfi, J.J., Kamalongo, D., Ngwira, N.,Odgaard, R., Nielsen, N.E.,HøghJensen, H., 2006. Yields and accumulation of $\mathrm{N}$ and $\mathrm{P}$ in farmer-managed intercrops ofmaize-pigeonpeain semi-arid Africa. Plant Soil, 285: 207-220.

Nuri, L.T. (2018). Determinants of market participation performance among poultry product producers: The case of Lemo District of Hadiya Zone, Southern Ethiopia. Journal of Economics and Susutainable Development Volume 9, No. 5, 2018.

Obi, A., Pote, P. and Chianu, J. (2011). Market Access: Components, Interactions, and Implications in Smallholder Agriculture in the Former Homeland Area of South Africa. Innovations as Key to the Green Revolution in Africa, 1161-1167.

Odeny, D.A. 2007. The potential of pigeonpea (Cajanus cajan (L.) Millsp.) in Africa. Natural Resources Forum 31: 297-305

Ohajianya, D.O. and Ugochukwu, A.I. (2011). An ordered Probit Model Analysis of Transaction costs and Market Participation by Sweet Potato Farmers in South Eastern Nigeria.

Okello, J.J., Kirui O.K. and Gitonga, Z. (2012). A Triple Hurdle Analysis of the use of Electronic-based Agricultural Information Services: The case of smallholder farmers in Kenya. A Paper prepared for presentation at the International Association of Agricultural Economists Triennial Conference (IAAE), August 18-24 2012,Foz do Iguacu, Brazil.

Oldeny, D.A. (2007). The Potential of Pigeon Pea in Africa. Natural Resource Forum 31(4), 297-305.

Omiti, J.M. (2009).Factors affecting the Intensity of Market Participation by Smallholder Farmers: A Case Study of Rural and Peri-Urban areas of Kenya. African Journal of agricultural and Resource Economics, Vol. 3(1):57-82.

Otieno, D.J., Nyanamba, T. and McCullough, E. (2009). Market Participation by Vegetable Farmers in Kenya: A Comparison of Rural and Peri-Urban Areas. African Journal of agricultural Research, Vol. 4(5):451-460

Otieno, Z., Okello, J., Nyikal, R., Wang'ombe, A., and Clavel, D. (2011). The role of varietal traits in adoption of improved dryland crop varieties: the case of pigeon pea in Kenya. African Journal of Agriculture and Resource economics. Volume 6, No. 2 september, 2011.

Recha, J., Kinyangi, J., and Omondi, H., (2012). Climate related risks and opportunities for agricultural adaption and mitigation in semi-arid eastern Kenya. Climate change, agriculture and food security. Cigar

Renkow, M., Hallstrom, D. G., and Karanja D.D. (2004). Rural infrastructure, transaction costs and market participation in Kenya. Journal of Developmental Economics. 73(1),349-367.

Reyes, B., Donovan, C., Bernsten R. and Maredia, M. (2012):Market Participation and sale of Potatoes by 
smallholder farmers in the Central Highlands of Angola: a Double Hurdle Approach. Paper prepared for presentation at the International Association of Agricultural Economists Triennial Conference (IAAE), August 18-24, 2012,Foz do Iguacu, Brazil.

Ricker-Gilbert, J., Jayne T.S., and Chirwa, E. (2011). Subsidies and crowding out. A Double -Hurdle Model of Fertilizer Demand in Malawi. American Journal of Agricultural Economics, 93(1), 26-42.

Sheahan, B.M. (2011). Analysis of Fertilizer use and Profitability in Kenya. Msc Thesis, Department of Agriculture, Food and Resource Economics, Michigan State University, USA.

Shiferaw, B., Okello J., Muricho, G., Omitti, J., Silim, S., and Jones, R. (2008). Nlocking the potential of highvalue legumes in the semi-arid regions: analysis of the pigeon pea value chains in Kenya. International Crop Research Institute for Semi-Arid Tropics. Nairobi, Kenya.

Smale, M., Nagarajan, L., Diakite L., Audi, P., Grum, M. Jones R., and Weltzein, E. (2010). Tapping the potential of village markets to supply seeds in semi-arid Africa: a case study comparison from Mali and Kenya

Sogbedji JM, Van HM \& Agbeko KJ (2005) Cover Cropping and Nutrient Management Strategies for Maize Production in Western Africa. Agronomy Journal.10.2134/agronj2005.0025 Vol.98 No. 4, p. 883-889.

Walker,T.,S.Silim,B.Cunguara,etal.2015.PigeonpeainMozabique:anemergingsuccessstoryof cropexpansion in smallholder agriculture. Research Paper 78E. Ministry of Food Security and Directorate of Economics, Republic of Mozambique.

Wooldridge J.M. (2004). Introductory Econometrics: A Mordern Approach. Mason, Ohio:South-Western.

World Bank (2008) World Development Report 2008: Agriculture for Development. Washington D.C.

World Bank (2011) World Development Report 2008: Global Economic prospects. Washington D.C.

Yeboah, E., Fening, J. O., Ampontuah, A. (2004). The use of pigeon pea (Cajanus cajan) foramelioration of utisols in Ghana. Pp. 401-409. In: Bationo, A. (ed.). Managing nutrient cycles to sustain soil fertility in sub-Saharan Africa. Tropical Soil Biology and Fertility Institute of CIAT, Nairobi, Kenya. 